\title{
What are the Recurring Theories Regarding the Pathogenesis of Major Depressive Disorder?
}

Hassan Alawie, BASc Student [1]*, Jr-Chee Hu, BEng Student [2], Aidan McLeod, BEng Student [3]

[1] Department of Systems Design Engineering, University of Waterloo, Waterloo, Ontario, Canada, N2L 3G1

[2] Department of Biomedical Engineering, Ryerson University, Toronto, Ontario, Canada, M5B 2K3

[3] Department of Mechanical and Industrial Engineering, Ryerson University, Toronto, Ontario, Canada, M5B 2K3

*Corresponding Author: haalawie@uwaterloo.ca

\begin{abstract}
Introduction: Several theories regarding the etiology of Major Depressive Disorder (MDD) provoke challenges in defining the exact pathology of the disorder. Among these theories, the most recurring theories were the monoamine hypothesis, cytokine hypothesis, and endocrine factors. Each of these hypotheses are backed with neurobiological studies and provide unique insight on the etiology of MDD. The current state of the literature of MDD is confusing and complex. There are various theories that explain the pathogenesis of MDD, each supported with evidence from pre-clinical and clinical studies. In this review, we aim to explain the most common theories of MDD and identify connections to the pathological mechanisms of this disease.

Methods: A literature search considering inclusion/exclusion criteria was conducted to determine the different theories on the pathology of MDD and their limitations.

Results: Using the inclusion/exclusion criteria, 44 articles were analyzed to form the basis of our review. Three main theories were found to be the most recurring, the monoamine hypothesis, cytokine hypothesis, and endocrine factors.

Discussion: The monoamine hypothesis suggests that MDD is due to a deficiency of monoamines, specifically the hormone 5-HT, or serotonin. In contrast, the cytokine hypothesis proposes that the abnormal regulation of proinflammatory cytokines is linked to MDD through multiple facets. Finally, dysfunction of the hypothalamic-pituitary-adrenal axis is currently being studied as several papers have reported increased cortisol levels in patients with MDD, suggesting a relation between the two.

Conclusion: This paper investigates the recurring theories regarding the pathogenesis of Major Depressive Disorder. However, further analysis revealed that the theories contain several inconsistencies that weaken their respective arguments. This includes unanticipated latency of drug effects, contradictory reports, and failed replications. Many argue that these hypotheses are not the cause of Major Depressive Disorder, but rather a concomitant occurrence.

Major Depressive Disorder includes diverse symptoms with various external causes, a matter which makes it difficult to accurately define its pathology. Advanced neurobiological research enables easier diagnosis and the development of effective treatments used by clinicians. Consequently, it is imperative to have a thorough understanding of the pathologic process.
\end{abstract}

Keywords: major depressive disorder; hypothesis; monoamine; monoamine oxidase; cytokine; inflammation; microglia; HPA; endocrine

\section{Introduction}

Major Depressive Disorder (MDD) is a serious mental health disorder, in which an individual may experience five or more symptoms of depression, lasting for at least two weeks [1]. These symptoms may include sadness, lack of appetite, feelings of guilt and low self-esteem [1]. Due to its complex nature, there exists many unanswered questions with regards to the cause of this disorder, leading to the effectiveness of antidepressants remaining below 30\% [2].
However, the etiology of MDD is thought to involve different pathways that contribute to its wide range of symptoms [3].

The most popular hypothesis, the monoamine hypothesis, states that depression is the direct result of a deficiency in monoamines within particular neurons, specifically serotonin, dopamine, and norepinephrine [2]. Monoamines are neurotransmitters that regulate homeostatic and physiological functions and are released 
UNDERGRADUATE RESEARCH IN NATURAL AND CLINICAL SCIENCE AND TECHNOLOGY (URNCST) JOURNAL Read more URNCST Journal articles and submit your own today at: https://www.urncst.com

into the synapse where they are able to act on receptors [4]. The concentration of these monoamines have been shown to significantly regulate depressive symptoms. Serotonin is responsible for regulating factors such as anxiety, memory, guilt and mood [4] whereas dopamine is responsible for anhedonia, amotivation, reward and enthusiasm [5]. Norepinephrine deals with energy, arousal, memory, sleep and pain threshold [6]. The monoamine hypothesis expands upon the activation and cyclic pathways of monoamines, investigating what factors may lead to a decreased expression. The primary factor investigated within the monoamine hypothesis is monoamine oxidase (MAO).

Sahin et al. found that inhibiting the activation of this enzyme led to a stable concentration of the monoamines [7]. Current antidepressants typically regulate the concentrations of monoamines through the inhibition of degrading enzymes, such as MAO, or through altering the monoamine pathway [7].

Another recurring hypothesis, the cytokine hypothesis, states that the unregulated production of pro-inflammatory cytokines causes neuroinflammation which leads to symptoms of MDD [7]. Microglia and astrocytes typically play a role in the immune response in the Central Nervous System (CNS), leading to homeostasis in the brain. In an innate immune response, pro-inflammatory cytokines function to maintain neuroplasticity, neuronal excitability, and neurogenesis. As a consequence of the inflammatory response, an over-activation of microglia and astrocytes (i.e. glial cells) may give rise to cytokine overexpression which leads to increased inflammatory factors [8]. The theory suggests that neurodegeneration and increased cytokine levels contribute to depressive symptoms. By analyzing the synthesis and pathways of the cytokines, such as IL-1 $\beta$ and TNF $-a$, mechanisms of mediating inflammatory response can be formulated.

Lastly, factors affecting the hypothalamic-pituitaryadrenal (HPA) axis may also play an imperative role in determining the pathology of MDD. The HPA axis serves as the body's primary stress response system [3]. Patients with MDD tend to have higher corticotropin-releasing factor (CRF) and cortisol hyper-secretion, both of which are activated by the cytokines [9]. HPA axis dysfunction has been shown to be commonly associated with patients suffering from MDD [3]. Schatzberg et al. also found that there may be a genetic factor that affects HPA function in response to stress [9].

Several different theories exist to explain the pathogenesis of this neurological disorder. Among these theories, the most recurring were the monoamine hypothesis, cytokine hypothesis, and endocrine factors. Each of these hypotheses are supported with neurobiological studies and provide a unique insight into the etiology of MDD. The explanation of these theories and their significance to the pathogenesis of MDD will help to elucidate the complexity of the various contributing factors to this disease. Additionally, analyzing the relations between the three hypotheses may give insight towards the current understanding of MDD, and possibly provide various potential research questions and/or therapeutic avenues.

\section{Methods}

The literature search was conducted using databases, ScienceDirect and PubMed. The inclusion criteria was as follows: i) qualitative studies published between 2000 and 2020 , ii) articles that focused on the pathophysiological mechanisms of MDD, iii) open-source papers. Alternatively, our exclusion criteria removed articles that focused on other types of depression that were not MDD.

The literature search was performed using the terms "MDD" along with the relevant hypothesis as the search term. For example, "MDD" AND "monoamine hypothesis", is a sample search term. To further narrow down search results, relevant keywords to the hypothesis were included in the search term.

Papers were only selected if they fit all the inclusion/exclusion criteria. Once selected, all authors contributed to the analysis of the paper to determine if the conclusion of the respective paper aligns with our topic. If there was a constant reference to a specific hypothesis, said hypothesis would be considered for further analysis in the paper. Further research into each specific hypothesis' limitations were also done to ensure its validity in the paper.

\section{Results}

The term "Major Depressive Disorder" was coupled with "hypothesis" as a search term, and returned 1,677 results, however, by using our inclusion/exclusion criteria, the total number of results became 92 . To be more specific in our search, we used the name of the hypotheses and a relevant term in order to gather articles more appropriate to each hypothesis. Altogether, a total of 44 articles were analyzed in total. The monoamine, cytokine, endocrine and neurodegeneration hypotheses were the most recurring and therefore, were initially considered in the paper.

The hypotheses chosen for analysis in this study were determined based on their recurrence during the research process, in addition to other factors. For example, the monoamine hypothesis was chosen due to it being one of the oldest accepted and most common hypotheses for MDD. Additionally, the cytokine and endocrine hypotheses were chosen due to their current popularity in experiments done from 2010-2020 and their closeness to each other.

Unfortunately, the neurodegeneration hypothesis was excluded as it did not have sufficient evidence to support the theory. Our research process indicated a heavy reliance on post-mortem studies, which is a probable cause for the insufficient evidence and thus the neurodegeneration hypothesis was not selected in our research process. 
UNDERGRADUATE RESEARCH IN NATURAL AND CLINICAL SCIENCE AND TECHNOLOGY (URNCST) JOURNAL

Read more URNCST Journal articles and submit your own today at: https://www.urncst.com

The highlights of the analyzed studies are shown in Table 1.

Several studies supported the monoamine hypothesis, namely the effects monoamines have on depressive symptoms. It was shown that deficiencies in dopamine and serotonin are associated with depressive symptoms, such as a lack of motivation and depressed mood respectively [4-5], while Egami et al. found that the norepinephrine pathway could be integral in determining personalized treatment for MDD [6]. Based on these studies, a link between levels of monoamines and pathophysiological effects of MDD was suggested.

Multiple studies experimented on the effects of cytokines on the brain through analysis of depressed patients versus healthy controls. The studies determined that depressed individuals showed elevated levels of cytokines, specifically TNF-a [10]. A study by Taene et al. demonstrated that increased stress levels, and thus elevated NLRP3 inflammasome activity, increases the development of depressive symptoms [11]. These studies therefore supported the connection between the concentration of cytokines and MDD symptoms.

From the literature search on endocrine factors, a particular study demonstrated varied HPA axis function depending on severity of depression in humans [12]. Nandam et al. demonstrated that the rate of the secretion of a specific hormone was altered in human patients with MDD [13]. Another possibility tested a genetic component in MDD, by indicating how a specific gene was associated with depression severity [9]. From these studies obtained in the literature search, the effects of different endocrine factors on MDD pathology was postulated.

Table 1. Summary of studies used in review from our inclusion/exclusion criteria

\begin{tabular}{|c|c|c|}
\hline $\begin{array}{l}\text { Hypothesis } \\
\text { (Monoamine, } \\
\text { Cytokine, Endocrine) }\end{array}$ & Main Finding & $\begin{array}{l}\text { (Source), } \\
\text { [Author, Year] }\end{array}$ \\
\hline Monoamine & $\begin{array}{l}\text { Analyzing the Norepinephrine pathway may help clinicians provide more } \\
\text { personalized treatment for heterogeneous diseases, such as MDD. }\end{array}$ & $\begin{array}{l}\text { [6], [Egami et al., } \\
2020]\end{array}$ \\
\hline Monoamine & $\begin{array}{l}\text { Studies have shown deficits in dopamine have been associated with } \\
\text { depression. }\end{array}$ & $\begin{array}{l}\text { [5], [Dunlop et al., } \\
2007]\end{array}$ \\
\hline Monoamine & $\begin{array}{l}\text { Although serotonin has influence on mood, it can be looked at as the sole } \\
\text { contributor to depressed mood }\end{array}$ & $\begin{array}{l}\text { [4], [Harmer et al., } \\
2009]\end{array}$ \\
\hline Monoamine & $\begin{array}{l}\text { Research in experimental animals have shown that dopamine is linked with } \\
\text { anticipation and thus motivation }\end{array}$ & $\begin{array}{l}\text { [11], [Salamone et } \\
\text { al., 2003] }\end{array}$ \\
\hline Cytokine & Depressed individuals showed elevated levels of cytokines such as TNF-a. & $\begin{array}{l}\text { [10], [Himmerich } \\
\text { et al., 2008] }\end{array}$ \\
\hline Cytokine & $\begin{array}{l}\text { Cytokines can have positive and negative effects on the brain as } \\
\text { demonstrated by analyzing the effects on depressed patients. }\end{array}$ & $\begin{array}{l}\text { [16], [Dowlati et } \\
\text { al., 2010] }\end{array}$ \\
\hline Cytokine & $\begin{array}{l}\text { Glial inflammatory mechanisms may play a major role in the pathology of } \\
\text { MDD }\end{array}$ & $\begin{array}{l}{[17],[\text { Kierdorf et }} \\
\text { al., 2013] }\end{array}$ \\
\hline Cytokine & $\begin{array}{l}\text { Elevated NLRP3 inflammasome activity has shown to increase the } \\
\text { development of depressive symptoms }\end{array}$ & $\begin{array}{l}\text { [11], [Taene et al., } \\
\text { 2019] }\end{array}$ \\
\hline HPA & $\begin{array}{l}\text { Confirmed presence of different hpa axis function between melancholic and } \\
\text { atypical depression }\end{array}$ & $\begin{array}{l}\text { [12], [Juruena et } \\
\text { al., 2011] }\end{array}$ \\
\hline HPA & $\begin{array}{l}\text { Studied } 66 \text { patients and } 29 \mathrm{HCs} \text {. Looked at genes that had to do with HPA } \\
\text { axis regulation. Discovered that the CRHR1 gene contributed significantly to } \\
\text { depression severity }\end{array}$ & $\begin{array}{l}\text { [9], [Schatzberg et } \\
\text { al., 2013] }\end{array}$ \\
\hline HPA & Feedback of ACTH secretion by cortisol is compromised in MDD & $\begin{array}{l}{[13],[\text { Nandem et }} \\
\text { al., 2020] }\end{array}$ \\
\hline
\end{tabular}


UNDERGRADUATE RESEARCH IN NATURAL AND CLINICAL SCIENCE AND TECHNOLOGY (URNCST) JOURNAL Read more URNCST Journal articles and submit your own today at: https://www.urncst.com

\section{Discussion}

This study aims to explain the most common hypotheses regarding the pathogenesis of MDD. Currently, a cure for MDD is not available, as it is a complex disease with various contributing factors to its pathology. As such, the current landscape of its etiology is filled with various theories, each supported with pre-clinical or clinical evidence. An explanation of the most recurrent theories of MDD will help shed light on the limitations of our understanding, and possibly pose potential therapeutic avenues. Based on our initial literature search, the most promising theories were the monoamine, cytokine and endocrine hypotheses. Each theory explains the pathogenesis of MDD in different ways, but there is also an interconnection between them. This will be discussed later on in this section. Briefly, the monoamine hypothesis states that the lowered levels of monoamines, such as serotonin, dopamine and norepinephrine are the primary cause of depressive symptoms [2]. The cytokine hypothesis asserts that pro-inflammatory cytokines are the primary factors involved in the formation of depressive disorders due to inflammatory effects [7]. The endocrine hypothesis provides an explanation for the development of depressive symptoms based on disturbances to endocrine systems such as the HPA axis [3]. These hypotheses are all associated with their own biological mechanisms that have been proven to contribute to depressive symptoms [3]. This discussion aims to go through each hypothesis, explaining in depth their relation to MDD.

\section{Monoamine}

The monoamines: dopamine, serotonin, and norepinephrine are neurotransmitters that are associated with regulating emotions related to joy and happiness within the Central Nervous System (CNS) [4-6]. It is theorized that a deficiency of monoamines may be a contributing factor to the common symptoms of depression [4-6]. The main monoamines that are thought to be involved in the pathogenesis of MDD are dopamine, serotonin and norepinephrine [4-6]. Deficiency in dopamine levels for example, has been shown to be associated with depressive symptoms [5]. Anhedonia, the reduced ability to feel pleasure or motivation and a common symptom of MDD, has been shown to be as a result of a downregulation of the dopaminergic system [5]. Research on rodents has shown that dopamine is associated with reward anticipation and impacts motivation levels [11]. These findings implicate dopamine as an important player in contributing to depressive symptoms. Additionally, an experiment by Harmer et al. on healthy volunteers demonstrated that antidepressants that increase serotonin concentration resulted in emotions that were completely opposite to those associated with depressed individuals [4]. These results demonstrate serotonin's antidepressant effects. An experiment by Egami et al. displayed different norepinephrine reuptake levels for healthy controls compared to depressed individuals, concluding the study by suggesting norepinephrine pathways as potential therapeutic targets [6]. This indicates not only a relation between norepinephrine and the disorder but indicates that more in depth research into these monoamines may provide a new therapeutic outlook. These studies support the notion that deficiency of monoamines is a possible contributor to the pathogenesis of MDD.

The monoamine hypothesis claims that monoamines are imperative to antidepressant effects in the body, therefore according to the hypothesis, the excessive metabolization of these monoamines results in depressive symptoms. The monoamine oxidase (MAO) family is a group of enzymes that are involved in the degradation of monoamines [14]. Monoamine oxidase A (MAO-A) has a greater affinity for serotonin and norepinephrine, while MAO-B has a greater affinity for dopamine [15]. A study by Bortalato et al. indicates the metabolic effects of MAO by demonstrating an $850 \%$ increase in brain levels of serotonin in the absence of MAO activity [15]. Since MAO regulates monoamine levels, it is conceivable that an increased activity of MAO will lead to a decreased concentration of monoamines in the CNS, which may contribute to the pathogenesis of MDD. Therefore, since MAO's reduce the amount of monoamines, it suggests a relationship between MAO levels and MDD.

\section{Cytokine}

The cytokine hypothesis suggests that MDD is a consequence of inflammation in the brain due to an increase in pro-inflammatory cytokines such as IL-1 $\beta$ and TNF-a. In response to stress, cytokines aid in maintaining plasticity and promoting neurogenesis [16]. However, the overexpression of cytokines IL-1 $\beta$ and TNF-a may cause negative effects by accelerating neurodegeneration, thus compounding stress on the brain [8]. A study by Himmerich et al. found that depressed patients demonstrated increased cytokine levels compared to healthy controls, suggesting that inflammation may play a role in the pathogenesis of MDD [10]. This supports the cytokine hypothesis by relating inflammation and those with depressive symptoms.

Chronic stress is believed to be an important factor in the pathology of MDD. Upon the detection of stress, glial cells respond by releasing cytokines, playing an important role in the CNS immune response [17-18]. Inflammatorybased immune response and the detection of signals such as stress, is controlled by the nod-like receptor protein 3 (NLRP3), which releases cytokines upon stress detection [11]. In a study by Zhang et al., NLRP3-null mice were subjected to mild stress for 4 weeks, including cage tilting/shaking, damp bedding and exposure to cold water for several hours [19]. Compared to control, the NLRP3null mice had a reduced expression level and activation of IL- $1 \beta$, indicating that NLRP3 plays a crucial role in the release of cytokines following stress stimuli [19]. 
UNDERGRADUATE RESEARCH IN NATURAL AND CLINICAL SCIENCE AND TECHNOLOGY (URNCST) JOURNAL Read more URNCST Journal articles and submit your own today at: https://www.urncst.com

Furthermore, this study suggests that the elevation of inflammasome activity as a result of stress is crucial in development of major depressive symptoms [11]. This study therefore suggests that stress and NLRP3 may be contributors to MDD pathology.

A study by Machado-Vieira et al. demonstrates decreased cytokine levels in the presence of MAO inhibitors [20]. Furthermore, antidepressants and possibly monoamine neurotransmitters may have effects on the activation of pro-inflammatory cytokines expression [8]. Since certain antidepressants act as MAOi, modulation of the monoamine pathways may have an effect on cytokine pathways, supporting the connection between the monoamine and cytokine hypotheses. This indicates a relation between monoamines and cytokines in the pathogenesis of MDD, supporting the idea that MDD is a heterogeneous disorder, by which multiple pathways contribute to its pathogenesis.

\section{Endocrine}

The endocrine hypothesis displays a relation between the impacts of stress and the pathogenesis of MDD, through analysis of the HPA axis. This is because the HPA axis is one of the most important components in regulating homeostasis in response to stress [21]. Figure 1 displays the mechanism by which the HPA axis responds to stress. An experimental study comparing adrenocorticotropic hormone (ACTH) response in healthy individuals compared to those with MDD concluded that the negative feedback mechanism of ACTH by cortisol was compromised in patients with MDD, resulting in an increased concentration of ACTH [13]. The authors suggested that glucocorticoid receptors in depressed patients may be impaired, resulting in an increase in ACTH levels [13]. Glucocorticoid receptors are one of two major receptors in the HPA axis during phases of prolonged stress [13]. Furthermore, the impairment of these receptors influences the homeostasis of the HPA axis, demonstrating a common pattern of increased levels of ACTH in depressed individuals. The findings from these studies provide evidence that support the theory that HPA axis dysfunction and the increased concentration of cortisol are possibly involved in the pathogenesis of MDD.

The complex nature of the pathogenesis of MDD has led scientists to test genetics as a contributing factor. Specifically, the corticotropin releasing hormone receptor 1 (CRHR1) gene is believed to be a contributing factor to HPA axis homeostasis [9]. In a recent study, Schatzberg et al. used a linear regression model was used to test if any genes could predict depression severity [9]. They found that the CRHR1 gene was the only one that was able to predict depression severity, as a result of the effects CRH has on the HPA axis. An unregulated increase of cortisol may influence HPA axis dysfunction, therefore increasing ACTH concentration, an attribute that was found to be more common in depressed individuals than healthy controls [13]. The effects of the CRHR1 gene is evidence that a genetic factor exists in the pathology of MDD. Ultimately, elevated levels of cortisol due to a dysfunctional HPA axis has proven to potentially be involved with the pathogenesis of MDD.

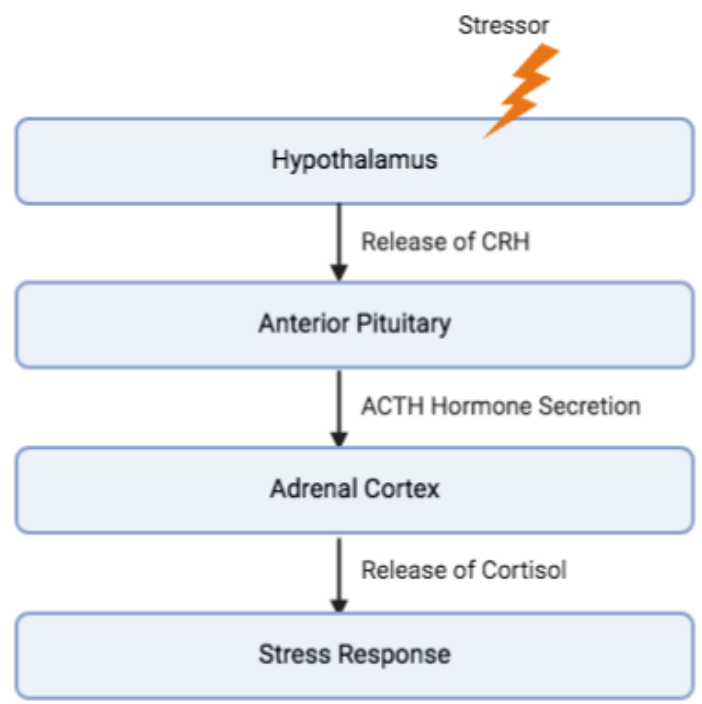

Figure 1. The response is initiated when NLRP3 releases cytokine IL-1 $\beta$, activating CRF in the hypothalamus. This results in the release of $\mathrm{CRH}$, increasing the ACTH hormone secretion from the adrenal pituitary. The ACTH hormone is then responsible for releasing cortisol from the adrenal cortex as a response to stress.

\section{Limitations}

Antidepressants and the monoamine hypothesis are interlinked, as antidepressants are typically found to act upon the monoaminergic system. However, a review analyzing the effectiveness of antidepressants identified their current limitations: i) approximately $50 \%$ of patients do not respond to their initial treatment, ii) $30 \%$ of patients do not respond to several treatments, and iii) there is a latent response in the effects of antidepressants [22]. The monoamine hypothesis serves as the basis for antidepressants, therefore their ineffectiveness in treating depressive symptoms can be used as a marker to determine the accuracy of the hypothesis.

Although the support of the cytokine hypothesis may be growing, there still remain questions in regard to its rationality. One of these questions, for example, is in regard to whether the presence of the influx of cytokines is a result of or a by-product of MDD [3]. Additionally, the complexity of the brain's inflammatory-immune response, in addition to the limited clinical evidence, are still challenges that the cytokine hypothesis faces [23]. More research is needed to understand the role that the cytokine hypothesis has in relation to the pathogenesis of MDD. 
UNDERGRADUATE RESEARCH IN NATURAL AND CLINICAL SCIENCE AND TECHNOLOGY (URNCST) JOURNAL Read more URNCST Journal articles and submit your own today at: https://www.urncst.com

Numerous studies have reported proportionality between the severity of depressive symptoms and cortisol levels [24]. A present-day systematic review analyzes whether HPA axis dysfunction is a result of MDD or early life stress (ELS). By including studies that incorporated patients with and without MDD or ELS, they theorized that there is a stronger link between HPA axis dysfunction and ELS than MDD [25]. This review also mentions the requirement for additional research to depict the exact mechanisms involved [25].

\section{Conclusion}

As demonstrated in this review, due to the complex nature of MDD, there are multiple theories that describe its pathogenesis. The most recurring theories found during our literature search were the monoamine and cytokine hypotheses, in addition to endocrine factors.

The monoamine hypothesis states that reduced levels of monoamines due to increased activity of MAO leads to depression. While, the cytokine hypothesis takes the position that cytokines cause inflammation in the brain, which further aggravates the stress response, leading to depressive symptoms. Lastly, the HPA axis plays an important role in regulating the active immune response as a result of stress, leading to an increased level of cortisol, causing MDD.

The combination of these theories contributes to unraveling the convoluted pathology of MDD. Perhaps by drawing connections between the various theories a deeper understanding can be obtained in order to design further research or develop treatment.

\section{List of Abbreviations Used}

MDD: major depressive disorder

MAO: monoamine oxidase

HPA: hypothalamic-pituitary-axis

CRF: corticotropic-releasing-factor

TOH: tryptophan hydroxylase

CNS: central nervous system

MTHFR: methylenetetrahydrofolate reductase

KF11: kruppel-like factor

NLRP3: nod-like receptor protein 3

$\mathrm{CRH}$ : corticotropin releasing hormone

ACTH: adrenocorticotropic hormone

CRHR1: corticotropin releasing hormone receptor 1

ELS: early life stress

\section{Conflicts of Interest}

The authors declare that they have no conflict of interests.

\section{Ethics Approval and/or Participant Consent}

As no new research was conducted, this study does not require an ethics approval. Additionally, no participants were included, requiring no need for participant consent.

\section{Authors' Contributions}

HA: contributed to the research process, drafted the work with the other authors, gave final approval for the final version.

$\mathrm{JH}$ : contributed to design of study, analysis of research, drafting the manuscript, approved of final version.

AM: made contributions to the design, drafting of manuscript, gave final approval.

\section{Acknowledgements}

The authors would like to acknowledge their mentor, Sumeya Mukhtar, for her consistent support during the research and writing process.

\section{Funding}

This study was not funded.

\section{References}

[1] Woelfer M, Kasties V, Kahlfuss S, Walter M. The Role of Depressive Subtypes within the Neuroinflammation Hypothesis of Major Depressive Disorder. Neuroscience. 2019 Apr ;403:93-110. https://doi.org/ 10.1016/j.neuroscience.2018.03.034

[2] Szałach ŁP, Lisowska KA, Cubała WJ. The Influence of Antidepressants on the Immune System. Archivum Immunologiae Et Therapiae Experimentalis. 2019 Jun 1;67(3):143-151. https://doi.org/10.1007/s00005-01900543-8

[3] Jesulola E, Micalos P, Baguley IJ. Understanding the pathophysiology of depression: From monoamines to the neurogenesis hypothesis model - are we there yet? Behavioural Brain Research. 2018 Apr; 341:79-90. https://doi.org/10.1016/j.bbr.2017.12.025

[4] Harmer CJ, Goodwin GM, Cowen PJ. Why do antidepressants take so long to work? A cognitive neuropsychological model of antidepressant drug action. British Journal of Psychiatry. 2009 Aug;195(2):102-8. https://doi.org/10.1192/bjp.bp.108.051193

[5] Dunlop BW, Nemeroff CB. The Role of Dopamine in the Pathophysiology of Depression. Archives of General Psychiatry. 2007 Mar 1 ;64(3):327. https://doi.org/10.1001/archpsyc.64.3.327

[6] Egami M, Imamura Y, Nabeta H, Mizoguchi Y, Yamada S. Saliva levels of 3-methoxy-4hydroxyphenylglycol and clinical efficacy of mirtazapine or selective serotonin reuptake inhibitors in patients with major depression. Human Psychopharmacology: Clinical and Experimental. 2012 Nov 5; 28(1):7-14. https://doi.org/10.1002/hup.2273

[7] Sahin C, Aricioglu F. Future Directions of Cytokine Hypothesis in Depression: 'NLRP3 inflamazomu.' Klinik Psikofarmakoloji Bülteni-Bulletin of Clinical Psychopharmacology. $2013 \quad$ Sep;23(3):280-8. https://doi.org/10.5455/bcp.20130927070724 
UNDERGRADUATE RESEARCH IN NATURAL AND CLINICAL SCIENCE AND TECHNOLOGY (URNCST) JOURNAL

Read more URNCST Journal articles and submit your own today at: https://www.urncst.com

[8] Sochocka M, Diniz BS, Leszek J. Inflammatory Response in the CNS: Friend or Foe? Molecular Neurobiology. 2017;54(10):8071-8089. https://doi.org/ 10.1007/s12035-016-0297-1

[9] Schatzberg AF, Keller J, Tennakoon L, Lembke A, Williams G, Kraemer FB, et al. HPA axis genetic variation, cortisol and psychosis in major depression. Molecular Psychiatry. 2013 Oct 29;19(2):220-7. https://doi.org/10.1038/mp.2013.129

[10] Himmerich H, Fulda S, Linseisen J, Seiler H, Wolfram G, Himmerich S, et al. Depression, comorbidities and the TNF- $\alpha$ system. European Psychiatry. 2008 Sep;23(6):421-9. https://doi.org/10.1016/j.eurpsy.2008 .03 .013

[11] Taene A, Khalili-Tanha G, Esmaeili A, Mobasheri L, Kooshkaki O, Jafari S, et al. The Association of Major Depressive Disorder with Activation of NLRP3 Inflammasome, Lipid Peroxidation, and Total Antioxidant Capacity. Journal of Molecular Neuroscience. 2020 Jan 1;70(1):65-70. https://doi.org/ 10.1007/s12031-019-01401-0

[12] Juruena MF, Calil HM, Fleck MP, Del Porto JA. Estudos latino-americanos sobre melancolia: um transtorno do humor melhor definido para o CID-11. Revista Brasileira de Psiquiatria . 2011 May;33 (suppl 1): s37-47. https://doi.org/10.1590/S151644462011000500005

[13] Nandam LS, Brazel M, Zhou M, Jhaveri DJ. Cortisol and Major Depressive Disorder-Translating Findings From Humans to Animal Models and Back. Frontiers in Psychiatry. 2020 Jan 22;10. https://doi.org/ 10.3389/fpsyt.2019.00974

[14] Soliman A, Bagby RM, Wilson AA, Miler L, Clark M, Rusjan P, et al. Relationship of monoamine oxidase A binding to adaptive and maladaptive personality traits. Psychological Medicine. 2011 May 1 ;41(4.):10511060. https://doi.org/10.1017/S0033291710001601

[15] Bortolato M, Shih JC. Behavioral outcomes of monoamine oxidase deficiency: preclinical and clinical evidence. International Review of Neurobiology. 2011; 100:13-42. https://doi.org/10.1016/B978-0-12-3864673.00002-9

[16] Dowlati Y, Herrmann N, Swardfager W, Liu H, Sham L, Reim EK, et al. A Meta-Analysis of Cytokines in Major Depression. Biological Psychiatry. 2010 Mar;67(5):446-57. https://doi.org/10.1016/j.biopsych .2009 .09 .033
[17] Kierdorf K, Prinz M. Factors regulating microglia activation. Frontiers in Cellular Neuroscience. 2013;7. https://doi.org/10.3389/fncel.2013.00044

[18] Kovaru H, Pav M, Kovaru F, Raboch J, Fiserova A. Cell signalling in CNS and immune system in depression and during antidepressant treatment: focus on glial and natural killer cells. Neuro Endocrinology Letters. 2009;30(4):421-428

[19]Zhang Y, Liu L, Liu Y-Z, Shen X-L, Wu T-Y, Zhang $\mathrm{T}$, et al. NLRP3 Inflammasome Mediates Chronic Mild Stress-Induced Depression in Mice via Neuroinflammation. International Journal of Neuropsychopharmacology. 2015 Jan 20;18(8): pyv006-pyv006. https://doi.org/10.1093/ijnp/pyv006

[20] Machado-Vieira R. Abnormal function of monoamine oxidase-A in comorbid major depressive disorder and cardiovascular disease: Pathophysiological and therapeutic implications (Review). Molecular Medicine Reports. 2012 Sep 4; https://doi.org/10.3892/mmr .2012 .1062

[21] Juruena MF, Calil HM, Fleck MP, Del Porto JA. Estudos latino-americanos sobre melancolia: um transtorno do humor melhor definido para o CID-11. Revista Brasileira de Psiquiatria. 2011 May 33 (suppl 1): s37-47. https://doi.org/10.1590/S151644462011000500005

[22] Mahar I, Bambico FR, Mechawar N, Nobrega JN. Stress, serotonin, and hippocampal neurogenesis in relation to depression and antidepressant effects. Neuroscience \& Biobehavioral Reviews. 2014 Jan; 38:173-92. https://doi.org/10.1016/j.neubiorev.2013 .11 .009

[23] Kohler O, Krogh J, Mors O, Eriksen Benros M. Inflammation in Depression and the Potential for AntiInflammatory Treatment. Current Neuropharmacology. 2016 Aug 26;14(7):732-42.

[24] O'Leary OF, Dinan TG, Cryan JF. Faster, better, stronger: towards new antidepressant therapeutic strategies. European Journal of Pharmacology. 2015 Apr 15; 753:32-50. https://doi.org/10.1016/j.ejphar .2014 .07 .046

[25] Heim C, Mletzko T, Purselle D, Musselman DL, Nemeroff CB. The Dexamethasone/CorticotropinReleasing Factor Test in Men with Major Depression: Role of Childhood Trauma. Biological Psychiatry. 2008 Feb ;63(4):398-405. https://doi.org/10.1016/ j.biopsych.2007.07.002 
UNDERGRADUATE RESEARCH IN NATURAL AND CLINICAL SCIENCE AND TECHNOLOGY (URNCST) JOURNAL

Read more URNCST Journal articles and submit your own today at: https://www.urncst.com

\section{Article Information}

Managing Editor: Jeremy Y. Ng

Peer Reviewers: Sumeya Mukhtar, Pallavi Dutta

Article Dates: Received Nov 03 21; Accepted Jan 16 21; Published Jan 2621

\section{Citation}

Please cite this article as follows:

Alawie $\mathrm{H}, \mathrm{Hu} \mathrm{Jr}-\mathrm{C}, \mathrm{McLeod} \mathrm{A}$. What Are the recurring theories regarding the pathogenesis of major depressive disorder?.

URNCST Journal. 2021 Jan 26: 5(1). https://urncst.com/index.php/urncst/article/view/215

DOI Link: https://doi.org/10.26685/urncst.215

\section{Copyright}

(C) Hassan Alawie, Jr-Chee Hu, Aidan McLeod. (2021). Published first in the Undergraduate Research in Natural and Clinical Science and Technology (URNCST) Journal. This is an open access article distributed under the terms of the Creative Commons Attribution License (https://creativecommons.org/licenses/by/4.0/), which permits unrestricted use, distribution, and reproduction in any medium, provided the original work, first published in the Undergraduate Research in Natural and Clinical Science and Technology (URNCST) Journal, is properly cited. The complete bibliographic information, a link to the original publication on http://www.urncst.com, as well as this copyright and license information must be included.

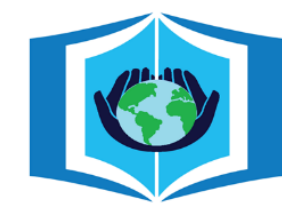

\section{URNCST Journal}

"Research in Earnest"

\section{Funded by the \\ Government \\ of Canada}

\section{Canadà̀}

Do you research in earnest? Submit your next undergraduate research article to the URNCST Journal!

|Open Access | Peer-Reviewed | Rapid Turnaround Time | International |

| Broad and Multidisciplinary | Indexed | Innovative | Social Media Promoted |

Pre-submission inquiries? Send us an email at info@ urncst.com | Facebook, Twitter and LinkedIn: @ URNCST

Submit YOUR manuscript today at https://www.urncst.com! 